Мринська Н. А., аспірант кафеери культурології та фбілособфської антропологї Національного педагогічного університету імені М. П. Драгоманова

\title{
МУЖНІСТЬ БУТИ ОСОБИСТІСТЮ В СИТУАЦІЇ ІНВАЛІДНОСТІ
}

Анотація. У статті проаналізована концепція «мужності бути особистістю» у ситуації інвалідності на основі роботи Пауля Тілліха «Мужність бути» та за допомогою метаантропологічного методу, розробленого Назіпом Віленовичем Хамітовим.

Інвалідність автором розглядається як ситуація, у якій людина втратила цілісність тіла внаслідок фатального яинника впливу, що призвело лише до часткової втрати тілесної цілісності (ампутація).

Концепт Пауля Тілліха дозволяє розглядати різни види тривоги людини щодо власних учинків чи ситуацій, у яких вона опинилась чи може опинитися протягом життя. Категоріями метаантропологічного аналізує буденне, граничне та метаграничне буття в ракурсі зовнішніх чинників впливу на буття людини та внутрішнього стану як частини тривоги людини щодо свого існування. Буття впливає на людину щодо іï попереднього, теперішнього та майбутнього, зміна стану створює нові виміри сприйняття свого існування та потребує трансформації під ситуаційні потреби. Середовище, у якому перебуває людина до, у момент чи після трансформації тіла, відображає різку зміну поглядів, відчуття та сприйняття ситуації. Стан інвалідності як різка зміна всіх звичних цінностей створює нову реальність, трансформує подальше життя людини.

Основою дослідження слугує концепт «мужність особистості», іiї трансформація в різних екзистенціальних вимірах буття. На думку автора, метаантропологія пояснює стан людини, яка опинилась у ситуації інвалідності, та дозволяє відокремити ту «мужність», за допомогою якої людина може подолати стан інвалідності як екзистенціальної кризи.

Ціль статті - виявити стани людини, яка перебуває в ситуації інвалідності, та знайти продуктивний шлях до нового, повноцінного існування.

Актуальність статті зумовлена сучасними реаліями України як країни, яка перебуває у стані військового конфлікту. Інвалідність стає не винятком, а частиною життєвого процесу всієї країни. Тема статті $є$ актуальною у визначенні саме автора як людини-інваліда в пошуку виходу із проблемної зони за допомогою методів та інструментів філософської антропології. Дослідження від інваліда і щодо інвалідів - це саме те, чого потребує суспільство. Саме це дослідження спроможне відкрите не тільки зовнішні прояви проблематики, а і внутрішні, приховані точки сприйняття миру самого інваліда.

Ключові слова: «мужністьбути», особистість, мужність бути особистістю, буття, буденне буття, граничне буття, позамежне буття, метаграничне буття, метаантропологія, трансценденція.

Постановка проблеми. Філософське розуміння проблеми людини, що опинилась в ситуації інвалідності, вимагає аналізу й аргументованого обгрунтування для ïiі вирішення. На тлі зростання уваги до інвалідів у суспільстві ця проблема потребує окремого розкриття теми в ракурсі вивчення витоків екзистенціальних почуттів особистості-інваліда. У ситуації інвалідності для особистості відкриваються процеси екзистенціального заглиблення в поняття «мужність» як можливості подолання відчаю й актуалізації свого життя в новому просторі, новому собі. Аналіз проблеми може знайти вихід із ключами системної методології метаантропології щодо розкриття суті мужності для особистості, заглибленої в переживання свого нового стану - інвалідності.

Аналіз останніх досліджень і публікацій. Філософська література пропонує великий спектр для осмислення проблеми мужності. У роботах Платона Сократ так і не дає відповіді на це питання, але висуває низку визначень, які сам і спростовує [5]. Фома Аквінський пов'язує мужність із Божим даром [2]. Сенека відносить їі до розумної визначеності, пов'язуючи «мужність бути» $\mathrm{i}$ «мужність померти» [6]. Для Ф. Ніцше мужність пов'язана із самоствердженням [4].

Основною базовою роботою можна вважати працю Пауля Тілліха «Мужність бути» [7]. Але жодна 3 робіт не дає розуміння феномену інваліда в контексті «мужністю бути особистістю». Повноцінність і всеохоплення дослідження стає можливим на основі методології метаантропології. Метаантропологія як система усвідомлення буття запропонована українським філософом Н. Хамітовим, є універсальним інструментом для вивчення особистості в різних життєвих ситуаціях.

Метаантропологія формується на базисних основах світосприйняття самої особистості на етапі вибору «повноти життя». «Повнота життя - наповненість його змістом, який $€$ результатом неповторно-особистісного буття» [12, с. 110]. Спосіб життя і ставлення до нього створюють основні позиції особистості на різних рівнях буття.

На першому етапі для розгляду поставленого завдання необхідно визначити просторові рамки. Такими рамками є буття людини і прояв іiі мужності на особистому плані. «Існує певна послідовність ступенів, дотримуючись яких при побудові світу первобутнє буття все більше схиляється до себе самого, щоб на більш високих щаблях, в усе нових вимірах впізнавати себе саме, щоб, нарешті, в людині повністю володіти собою і осягати себе» [ 9, с. 157]. М. Хайдеггер так само впевнений, що буття - це ланцюжок, що визначає концепції суті буття. «Не «в колі доведення» лежить питання про сенс буття, але мабуть дивна «назад- або вперед-віднесеність» спрощеного (буття) до запитування буденного модусу сущого» $[10$, c.157].

Саме це пропонує метаантропологія, розділяючи буття на екзистенціальні виміри із властивими їм характеристиками. 
Н. Хамітов виділяс три основні виміри буття: буденне буття, граничне буття і метаграничне буття. Характеризуючи буденне буття, автор пише: «Буття людини вимірюється іï адаптацією до матеріального життя суспільства» [12, с. 109]. Буденне буття несе буденність існування, «буденність (звичайне буття людини) - це все те звичайне, що оточує нас, не дає проявитися неповторному особистому витоку» [11, с. 224]. Граничне буття - «буття-на-межі - це повстання проти соціальної заданості людського життя, прорив до свободи» [12, с. 111]. «Граничне буття, або буття-на-межі, може бути визначено як вихід за межі буденності, з ії гармонією, у дисгармонійний стан» [11, с. 257].

Метаграничне буття створюе вихід за межі буденності, актуалізуючи нове гармонійне поле для прояву особистості: «творення свого життя як цілісності і розуміння його сенсу, а в результаті - набуття повноти життя, якої позбавлені і буденність, і екзистенція» [12, с. 113] .

Створюючи концепцію метаантропології, Н. Хамітов припустив, що людина не може постійно перебувати у вимірі одного буття, $і$ iіi життя поділене на певні виміри.

Кожна людина, перебуваючи в одному з вимірів буття, періодично виходить за його межі під впливом обставин зовнішнього світу. Цей перехід змушує ії переміщатися на інший, більш високий або нижчий вимір буття. Якщо уявити собі ці три типи буття у вигляді автономних просторів, які розташовуються в загальному вселенському вимірі, то будь-який вихід за межі свого буття характеризує руйнування i, можливо, повну анігіляцію буття, з якого людина виходить у даний момент часу. Такий перехід веде до зміни не тільки самої людини, але і її уявлень щодо попереднього буття. Отже, повернувшись із тимчасового буття в попередне, зміниться не тільки сама людина, a і звичне сприйняття буття.

Другим рівнем усвідомлення даного дослідження є розуміння особистості та іiї характеристики щодо різних категорій буття. Аналізуючи особистостей за вимірами буття, ми визначаємо, - це людина буденного буття, людина граничного буття і людина метаграничного буття. Буденне буття привносить у життя людини турботу щодо базових потреб: «життя (людини в буденному бутті) повністю підпорядковане волі до самозбереження і продовження роду» [12, с. 110].

Розглядаючи людину у граничному бутті та іiі основні засади, бачимо «з'ясування можливостей переходу життя-буденності в екзистенцію як (граничну) реальність життя і виявлення умов гармонії життя й екзистенції» [12, с. 113].

Людина, відкидаючи одноманітність буденного буття і трагізм граничного буття, створює простір гармонійного буття, метаграничного (позамежного), яке «відчинене назустріч світу, у ньому з'єднується особистісне і вселенське» [12, с. 113].

Але чи на всіх рівнях буття людина є особистістю? Сам автор методу характеризує ставлення до особистості в межах буденного буття, «підкоритись соціальному інстинкту - значить стати не особистістю» [12, с. 145]. На рівні граничного буття людина стає особистістю, відпустивши всі прояви тілесності, занурюючись в екзистенцію духу. Екзистенція проявлясться як прагнення душі. Страх за себе на рівні тіла вже є несуттєвим, генерується вболівання за душу. Н.Хамітов пише: «Жах - це страх не за тіло, а за душу. Це страх за особистість» [12, с. 158]. Простір метаграничного (позамежного) буття неможливий без розкриття «творчого вдосконалення особистості і безмежності ії волі» $[12$, с. 115$]$.
Отже, у метаантропологічній системі особистістю слід вважати людину, що відкинула стереотипи і $€$ індивідуальністю, пізнавши свою значущість у соціумі. Така особистість має своє прагнення, має ідентичність, здатна до самоаналізу і самовизначення.

Третій рівень оперує поняттям «мужність», а конкретніше, «мужність бути», «мужність бути стає можливою тому, що вона $є$ часткою у самоствердженні самого буття» [7, с. 7]. Якщо відкинути всю матеріальність твердження «Буття визначає свідомість», яке висуває К. Маркс, і перекласти це визначення на критерії антропології, відкривається інший ракурс цього висловлювання від П. Тілліха: «Сутність людини є iї існування» $[7$, с. 7].

Залежно від способу життя формуються спосіб мислення, рівень усвідомленості та рівень прояву себе в розумінні «бути». «Бути» у рамках буденного буття дорівнюе «споживати». «Бути» у межах граничного буття - «випробування». «Бути» на рівні метаграничного буття - «самовираз». Отже, переживання мужності здійснює трансформацію під впливом буття.

Буденне буття створює для мужності настанову лише на рівні «вижити», призводить до дії рефлекторної, спрямованої цілком на захист, i це мужність без міркувань, без духу мужності. Вона не торкаєтеся особистості, а лише захищає фізичне тіло. Дія, але спрямована духом мужності, може бути лише на наступному рівні буття, граничному. Граничне буття створюе для нас тривоги перед конкретним об'єктом або ситуацією, переводячи особистість з безособистісного поля у стан індивідуального початкового страху. На думку Пауля Тілліха, «страх - це боязнь чогось, наприклад, страждання, відчуження особистістю або групою, втрата чогось або когось, момент смерті» [7, с. 11].

Екзистенція граничного буття трансформує поняття «мужність» $\mathrm{y} \mathrm{«відвагу»,} \mathrm{відображаючись} \mathrm{через} \mathrm{індивідуальний} \mathrm{вчи-}$ нок, здатний перевести «мужність» у самовираження. «Самоствердження» не тільки відрізняється від «себелюбства» як негативної моральної якості, але навіть протилежне йому.

Самоствердження - це онтологічна протилежність, за П. Тілліхом, «редукції буття тими афектами, які не відповідають сутнісній природі людини» [7, с. 6]. Тільки метаграничне буття створює акт «мужності бути» у прояві індивідуального вчинку, творінні. Метою метаграничного буття $є$ самоствердження через співучасть у загальному акті творіння, пошук призначення. За міркуваннями П. Тілліха, «досконале самоствердження - це не ізольований акт, який зароджується в індивідуальному; вчинене самоствердження $€$ співучасть в універсальному, чи божественному акті самоствердження, яке породжує сила кожного індивідуального акту» [7, с. 7].

У прагненні знайти виходи для людини у стані інвалідності завдяки мужності особистості, за принципами метаантропологічних вимірів, виникає рішення, що єдиний шлях виходу із граничного буття для інваліда - шлях трансценденції.

Розглядаючи ситуацію з набутою тілесною інвалідністю як роль фатуму, варто визначити місце і становище особистості в контексті метаантропологічної парадигми для такої людини.

У нашому дослідженні інвалідність розглядається як трагічна випадковість, що призвела до втрати тілесної гармонії 3 повним усвідомленням можливості смерті і подальшим пошуком нового сенсу життя. Це визначення ставить інваліда в екзистенцію граничного буття, де він як особистість з'являється миттєво, незалежно від своїх бажань. 
В екзистенціальний стан його занурюють не думки, не тривоги, не зовнішне відчуження, а фатум, який створює прецедент поглиблення в екзистенцію. Фатум як феномен, заглибивши інваліда водночас у жах, відчай, дезорієнтує його в полі буденного буття, створюючи порожнечу: втрату сенсу життя на особистому плані, відсутність ролі у структурі соціуму. Усе це переміщує з буденного у граничне буття. Такі різкі зміни для інваліда межують 3 небуттям, «порожнеча і втрата сенсу суть вираження небуття» [2, с. 7]. Це небуття залишає його в рамках граничного буття із зяючою порожнечею відчаю. Якщо, дотримуючись традицій атомізму, прийняти, що «не буття» - порожнеча, тоді сенсу в порожнечі бути не може, і вирішення справи заходить у глухий кут. Олексій Федорович Лосєв уважає, що коли немає нічого, крім буття, то небуття слід виводити з такого буття, яке саме себе обмежує [3].

Існуючі рамки обмеження генерують прагнення їх зламати, але ситуація інвалідності позбавляс сили, інваліду доводиться мириться з небуттям. Георг Вільгельм Фрідріх Гегель у праці «Наука логіка» говорить про вічну трансформацію буття в небуття і визначає, що вони рефлексивні, а їхні відмінності це надія на небуття як інше буття [1]. Але будь-що інше вимагас відмінної оцінки від звичного, інвалід сприймає це не просто іншим, а істотно зміненим від звичайного стану. А. Чанишев уважас, що буття - тільки тінь небуття, його виворіт [8]. Тобто «не бути», у ситуації, коли особистість стає інвалідом, так само просто, як «бути». Бути особистістю в цьому випадку і проявляти мужність просто неможливо, тому що ти перебуваєш у стані «невияву». У «невияві» відсутній сам факт дії, i фізичної, і емоційної.

Боротьба в небутті стає приреченою на поразку, єдиний вихід із порожнечі - у порожнечу. Пауль Тілліх уважає, що сама порожнеча виводить людину зі стану самозаперечення, «саме це перешкоджає тій схильності до самогубства, що криється в порожнечі і відсутності сенсу» [7, с. 15]. Макс Шеллер міркує по-іншому, акцентуючи, що розум людини здатний заповнювати порожнечу самостійно, незалежно від глибини порожнечі: «Знову опредметнити свій фізіологічний і психічний стан і навіть кожне окреме психічне переживання. Лише тому можливо вільно відкинути життя» $[9$, с. 156$]$.

Визначивши самогубство як акт і дію, П. Тілліх визнає, що в порожнечі дія не може бути дією, тому що вона стає лише онтологічним явищем. Тому саме прагнення самогубства - це не дія. Але якщо людина робить певні кроки до самознищення, то це варто розглядати як дію в порожнечі, як акт мужності, тоді самозаперечення стає виходом із небуття у граничне буття. Будь-яке усвідомлення себе як особистості в небутті, трансформоване актом дії, здатне викликати екзистенцію, отже, повернення до граничного буття, шляхом емоційного шоку.

Перебування в постійному стані екзистенції і $€$ сам акт мужності у граничному бутті. «Мужність - це самоствердження буття всупереч факту небуття» [7, с. 46]. Створюючи й інтегруючи переживання в собі, людина створює той тонкий зв'язок небуття з буттям, нехай на межі та в постійному стані страху, болю, відчаю. «Біль відчаю виникає тому, що буття усвідомлює неспроможність стверджувати себе всупереч силі небуття» [7, с. 16].

Перебування у граничному стані та у граничному бутті сприймається особистістю в ситуації інвалідності певним «якорем», у спробі перебудувати реальність. Граничне буття стає настільки звичним, а прояв мужності в ньому настільки перманентним, що вивести особистість зі стану межі, за допомогою прийняття ситуації, практично неможливо.

Перетворення чуттєвого прояву мужності, де моральні закони й особисті переконання змушують залишатися в бутті, заперечуючи порожнечу. Утримання себе від самовідчуження призводить до парадокса - не жити в розпачі, це здається єдиним виходом. Воля як інструмент мужності стає пасивною, i всі зусилля для іiі прояву спрямовані в середину. «Мужність потребує сили буття, у силі трансцендуючого небуття, яке відображається у тривозі за долю і смерть, відчувається у тривозі, порожнечі і відсутності сенсу, присутнє у тривозі провини i засудження. Мужність, яка приймає цю потрійну тривогу в себе, повинна бути вкорінена в силі буття більш, ніж сила індивідуального Я і сила цього світу Я» [7, с. 46]. Зовні про таку людину складається враження повного зречення або самоізоляції, що само собою правильно. Самоізоляція як інструмент абстрагування від зовнішніх проблем створює надійний додатковий кокон.

Перебування у стані докладання постійних вольових зусиль, спрямованих на утримання себе у стані «буття-намежі», для особистості єдина можливість відчувати себе живою. Особистість зайнята вирішенням внутрішніх суперечностей і конфліктів, що дивно для більшості людей. Особливо коли така ізоляція триває досить довго. Н. Хамітов зазначає: «В очах буденності граничне буття майже завжди виступає падінням. Це випадіння із загальних норм. І воно дійсно може стати падінням, якщо зупиняється на самому собі, свойй заперечності щодо буття, а не прагне до нової гармонії» [12, с. 111].

Перебування в екзистенціальній кризі може утримати звичайну людину у граничному бутті на період трансформації, переусвідомлення трагічної суперечності. Інвалід, з отриманням нового тіла, здатний усе життя перебувати у граничному стані, і буття в буденності може бути недосяжним.

Стан на межі не може бути вічним. Отже, для підтримки своєї внутрішньої значущості особистість у ситуації інвалідності може екзальтувати подібні стани, виводячи їх на новий рівень межі. Таких меж може бути безліч, але за кожною з них незмінно ховається втеча від порожнечі. Рішенням можуть слугувати два варіанти: прийняття самозаперечення як самоствердження через самознищення або прийняття через само-заново-творіння. Ці два виходи перенаправляють нас до двох полярних точок буття - буденного буття як падіння особистості та метаграничного (позамежного) буття як зростання особистості.

Дорога в буденне буття найбільш проста і легка. Буденне буття передбачає комфортне, звичне середовище для людини, де вона перекладає свою відповідальність на соціум. У цій ролі вона займає позицію жертви і незмінно вимагає до себе уваги.

Людина «особлива» трансформується в людину «значущу» завдяки увазі. Самоствердження відбувається завдяки жалості та прийняття турботи від інших. Положення в соціумі виділяється через обмеження «я не можу», значить, хтось повинен мені це дати. Особистість розчиняється в загальній масі споживачів турботи в найширшому сенсі слова. Вона втрачає по суті «мужність бути особистістю». «Присутність себе самого як власної здатності-бути-самістю < ..> відпала і впала у «світ»»» $[10$, c. 92$]$.

Участь людини зводиться до простежування важливості себе як споживача, заперечуючи водночас можливість віддачі. 
Для такої людини вкрай важливим стає «бути як всі», водночас виділяючи себе із загальної маси через свої недоліки, перетворюючи їх на показові, для отримання більшого.

Таких людей П. Тілліх називає сучасними циніками: «Сучасні циніки нездатні слідувати за будь-ким. У них немає ні віри в розум, ні критерію істини, ні системи цінностей, ні відповіді на питання про сенс. Вони намагаються порушити будьяку запропоновану їм норму. Їхня мужність виражається не у творчості, а у способі життя. Вони мужньо відкидають будьяке рішення, яке може позбавити їх свободи відкинути все, що вони хочуть відкинути. Циніки самотні, хоча вони потребують інших людей для того, щоб продемонструвати свою самотність» [7, с. 45].

Це все породжує суперечності на екзистенційному плані, але заглиблюватись у суперечності не $є$ метою для людини буденного буття. Тому вирішити їх вона намагається за допомогою цілковитої залежності, яка веде до самознищення. Ми часто зустрічаємо людей , що ведуть такий спосіб життя, що характеризують себе як скривджених. Алкоголь, наркотики і порушення соціальних норм стають найяскравішим виявом людини-споживача, яка уклала себе в рамки екзистенціальної безвиході.

Існує ще один шлях, який веде із граничного буття, це шлях трансцендування. У такому разі варто розглядати метаграничне (позамежне) буття і як джерело «мужності бути». Інвалідність стає відліком, індивідуум виступає величиною, здатною привести свої прагнення до більш високої мети існування. Шляхи та порядок дій можуть бути різними в сенсі самого буття.

Буття може виступати символом прагнення й основою для прояву особистості. У першому випадку ми знаходимо відповідь у зовнішній творчості, яка створює орієнтири для досягнення гармонійного позамежного буття. Можна погодитися із Н. Хамітовим, що «гармонія позамежного буття це гармонія здобуття свободи, як творчості свого життя, а також гармонія особистісного вирішення трагічних суперечностей життя» [12, с. 113].

У такому разі саме буття створює основу для нового прояву мужності - творіння себе нового. Обидва ці шляхи неможливі без однісі умови, яку необхідно прийняти ще на рівні граничного буття, це умова самоприйняття. «Самоприйняття неможливе, якщо ти не прийнятий у міжособистісні відношення. Але навіть якщо ми беремо себе як особистість, необхідно самотрансцендуюча мужність прийняти це прийняття, необхідна мужність довіри» [7, с. 49]. Безумовне прийняття себе це всього лише перший мужній крок на шляху до позитивного результату.

Шляхи, які пропонує П. Тілліх, схожі, їх можна умовно так само розділити на два типи: це духовний шлях $i$ шлях самовдосконалення.

Духовний шлях передбачає трансцендування через віру. Основою віри можуть служити і містичні, і релігійні, і навіть філософські концепції, хоча П. Тілліх уточнював, що не хотів би використовувати поняття «віра». Автор пише: «Я не використовував поняття «віра». Я робив це частково тому, що поняття віри втратило свій справжній сенс і набуло значення «вірування в неймовірне»»» [7, с. 49]. Узявши до уваги його твердження, нам здається доцільним застосувати подібне слово, бо він уточнює, що «віра, що робить можливою мужність відчаю, є при- йняття сили буття навіть у лещатах небуття» [7, с. 50]. У даному дослідженні слово «віра» найбільш виразне, бо включає в себе такі поняття: «віра в себе», «віра в Бога», «віра в диво», «віра в людей», «віра у свою мужність».

Наступним кроком можна вважати самотворення через відчуття свободи. Особистості, що пережила ситуацію інвалідності, необхідно знову вчитися найпростішим навичкам, ходити, їсти, пити, іноді - говорити, взаємодіяти з новим тілом. Відчувати, що нове тіло - це новий Я. Усвідомлення нового Я, веде до мужності «бути іншим». Тепер «інший Я» повинен творити себе нового. Інтенцією до прояву мужності може служити заперечення регресу або навіть ригідності особистості. Прагнення не бути в полоні свого тіла, небажання залежати від запропонованих можливостей, усе це може створити особисту свободу через прояви мужності. Мужність стає рушієм для процесу перевтілення. Сам же процес перетворення аналогічний із процесом творення. Сама людина, переживши глибоку травму, не тільки фізичну, а й екзистенційну, у стані транцендування з особливою силою волі, з особливим ентузіазмом, адже відступати ій немає куди.

У цій статті на основі аналізу поняття «мужність бути» у конкретній ситуації інвалідності розкрита ціль статті, зроблені висновки, що продуктивний вихід зі стану граничного буття можливий тільки через транцендування в позамежне буття.

Граничне буття - це буття, що зустрічає інваліда в момент отримання інвалідності. Граничне буття, завдяки своїй високій напрузі й амплітудному емоційному коливанню, виштовхує людину за свої межі. Можливі шляхи: у порожнечу, де діє «мужність не бути»; у повсякденне буття, де «мужність бути» трансформується в «мужність бажати», перетворюючи особистість на споживача; у метаграничне (позамежне) буття, де «мужність бути» розкривається як «мужність бути особистістю».

Лише транцендування в метаграничне (позамежне) буття здатне провести зміни у свідомості інваліда, від «мужності прийняти свою особистість» до «мужності бути новою особистістю».

Jimepamypa:
1. $\quad$ Гегель Г.В.Ф. Наука логіки : у 3-х т. Москва, 1970-1972.

2. Грабманн М. Введення в «Суму теології» св. Томи Аквінського. Москва : ІЛ, 2007.300 с.

3. Лосєв А. Буття. Ім'я. Космос. Москва, 1993.

4. Ніцше,Ф. Вибрані твори. Пер. $з$ нім. К. Свасьяна, Г. Рачинського, Ю. Антонівського. Санкт-Петербург, 2003. 765 с.

5. Платон. Федон, Бенкет, Федр, Парменід / за заг. ред. А. Лосєва та ін. ; пер. із. давньогр. С. Ананьїна та ін. Москва, 1999. 528 с.

6. Сенека Л. Моральні листи до Луцилія. Пер. С. Ошерова. Москва : Наука, 1977. 383 c.

7. Тілліх П. Мужність бути. Вибране / П. Тілліх. Пер. Т. Вевюрко. Москва : Юрист, 1995. С. 7-131.

8. Чанишев А. Трактат про небуття. Питання філософії. 1990. № 10. C. $158-162$.

9. Шелер М. Вибрані твори. / пер. : А. Денежкина, А. Малінкін, А. Філіппова ; за ред. А. Денежкина. Москва : Гнозис, 1994. 490 с.

10. Хайдеггер М. Буття і час. Пер. $з$ нім. В. Бібіхіна. Харків : Фоліо, 2003. $503 \mathrm{c}$.

11. Хамітов Н. Самотність у людському бутті . Досвід метаантропології. 2-ге вид., перероб. та доп. Київ : КНТ, 2017. 370 с.

12. Хамітов Н. Філософія: Буття. Людина. Світ : курс лекцій. Київ : KHT, 2017. $268 \mathrm{c}$. 
Mrinska N. The courage to be a person in a disability situation

Summary. The article analyzes the concept of "courage to be a person" in a disability situation, based on the work of Paul Tillich "Courage to be" and using the meta-anthropological method developed by Nazip Vilenovich Khamitov.

Disability by the author is considered as a situation in which a person loses body integrity due to a fatal influence factor and led only to a partial loss of body integrity (amputation).

The concept of Paul Tillich allows us to consider various types of anxiety of a person regarding his own actions or situations in which she finds herself, can be in the course of life. The categories of meta-anthropological analysis are everyday, ultimate, and meta-boundary being in the perspective of external factors of influence on a person's being and internal state, as part of a person's anxiety about his existence. Being influences a person in relation to her previous, present and future and a change in state, creates new dimensions of perception of her existence and requires transformation to situational needs. The environment in which a person is located before, at the time of or after the transformation of the body reflects a sharp change in attitudes, sensation and perception of the situation. The state of disability, as a sharp change in all familiar values, creates a new reality and transforms the future life of a person.
The basis of the study is the concept of "courage of the individual" and its transformation in various existential dimensions of being. According to the author, metaanthropology explains the state of a person, finds himself in a situation of disability and allows us to separate the "masculinity" with which a person is able to overcome the state of disability as an existential crisis.

The purpose of the article is to identify the state of a person who is in a disability situation and find a productive path to a new, full-fledged existence.

The relevance of the article is due to the modern realities of Ukraine, as a country in a state of military conflict. Disability is not an exception, but part of the life process of the whole country. The title of the article is relevant in certain particular author as people with disabilities in finding a way out of the problem area using the methods and tools of philosophical anthropology. Research from and to disabled people is exactly what society requires. It is this study that is capable of openly not only the external manifestations of the problem, but also the internal, hidden points of perception of the world of the disabled person.

Key words: "courage to be", personality, courage to be personality, being, everyday being, marginal being, extrinsic being, meta-boundary being, meta-anthropology, transcendence. 